\title{
Egzersize Bağlı Kilo Kaybı ve Glutatyon S-Transferaz
}

\author{
Exercise-induced Weight Loss and Glutathione S-Transferase
}

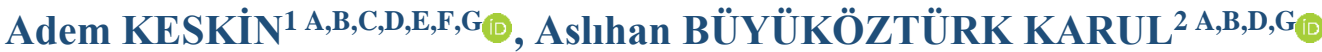 \\ ${ }^{1}$ Aydın Kadın Doğum ve Çocuk Hastalıkları Hastanesi, Aydın, Türkiye \\ ${ }^{2}$ Aydın Adnan Menderes Üniversitesi, Tıp Fakültesi Tıp Biyokimya Ana Bilim Dalı, Aydın, Türkiye
}

ÖZ

\begin{abstract}
Amaç: Bu çalışmada, egzersiz yaptırılan ratlarda gözlenen kilo kaybının, Glutatyon S-Transferaz enzim aktivitesi üzerine etkisinin araştırılması amaçlanmıştır.

Yöntem: Ratlara 10 günlük egzersiz yaptırıldı. Gruplar arası kilo kaybı farkı oluşması amacıyla bir gruba melatonin ve niasin verildi. Çalışma boyunca ratlar tartıldı. Son egzersizden bir gün sonra intrakardiyak kan örnekleri alındı. Glutatyon STransferaz enzim aktivitesi ölçüldü.

Bulgular: Gruplarda kilo kaybı gözlendi. Vücut ağırlığı dikkate alındığında, melatonin ve niasin verilen grupta oluşan kilo kaybının anlamlı olduğu gözlendi $(\mathrm{p}<0.001)$. Kilo kaybı daha yüksek olan bu grubun Glutatyon S-Transferaz enzim aktivitesi, diğer gruptan daha düşük olduğu gözlendi $(\mathrm{p}<0.001)$. Gruplarda gözlenen kilo kaybı ile analizi yapılan Glutatyon S-Transferaz enzim aktivite düzeyleri arasında zıt yönlü korelasyon olduğu gözlendi $(\mathrm{p}<0.001)$.

Sonuç: Bir grupta yaklaşık \%4 düzeyinde kilo kaybı oluştu. Egzersize bağlı kilo kaybı ile Glutatyon S-Transferaz enzim aktivitesi arasında zıt yönde bir korelasyon olduğu saptandı.
\end{abstract}

Anahtar Kelimeler: Egzersiz, Kilo kaybı, Glutatyon S-Transferaz.

\section{ABSTRACT}

Objective: In this study, it was aimed to investigate the effect of weight loss observed in exercised rats on Glutathione STransferase enzyme activity.

Methods: The rats were exercised for 10 days. Melatonin and niacin were given to one group in order to create a difference in weight loss between groups. The rats were weighed throughout the study. Intracardiac blood samples were taken, one day after the last exercise. Glutathione S-Transferase enzyme activity was measured.

Results: Weight loss was observed in the groups. It was observed that the weight loss in the melatonin and niacin group was significant, considering body weight $(\mathrm{p}<0.001)$. Glutathione S-Transferase enzyme activity of this group with higher weight loss was observed to be lower than the other group $(\mathrm{p}<0.001)$. There was an inverse correlation between the weight loss observed in the groups and the analyzed Glutathione S-Transferase enzyme activity levels $(\mathrm{p}<0.001)$.

Conclusion: Approximately $4 \%$ weight loss occurred in one group. There was an inverse correlation between exercise-induced weight loss and Glutathione S-Transferase enzyme activity.

Key words: Exercise, Weight loss, Glutathione S-Transferase.

\section{GİRIŞ}

Obezite her yaş, cinsiyet, etnik köken, rrk ve sosyoekonomik statüdeki bireyleri etkileyen küresel bir sağlık sorunudur (1). Amerika Kalp Derneği ve Amerikan Kardiyoloji Kolejinin yayınladığı bir kılavuzda, obezitenin tedavisi için başlangıçta vücut ağırlığının \%üç ila beşi kadar kilo kaybı önermektedir (2). Kilo kaybını elde etmek için ortak bir strateji; bir 
taraftan enerji alımını azaltırken, diğer taraftan enerji harcamasını artırarak zıt yönlü enerji dengesi oluşturmaktır (3).

Düzenli egzersiz, obezite tedavisindeki olumsuz tabloyu iyileştirmek için büyük potansiyele sahip bir strateji olarak ortaya çıkmıştır (4-6). Bununla birlikte, fiziksel aktivitenin, kilo verme üzerindeki klinik etkinliği, birçok tartışmanın konusu olmuştur (7). Egzersiz, süresine ve yoğunluğuna bağlı olarak oksidatif stres düzeyinde bir artışa neden olmaktadır. Çok yoğun bir egzersiz programı esnasında tüm vücut, normal istirahat haline göre yaklaşık 20 kat oksijen kullanırken bu oran egzersize katılan kaslarda 200 kata kadar ulaşabilmektedir (8).

Ashtary-Larky ve arkadaşlarının yaptıkları çalışmada; Yavaş kilo kaybının vücut kompozisyonu bakımında daha elverişli olduğu sonucuna ulaşmışlardır (9). Buna ek olarak, şiddetli diyet kısıtlaması üzerine yapılan bir sistematik derlemede ise; Önemli sayıda insanın, hızlı kilo kaybının yan etkileri olduğuna ve yavaş kilo kaybına benzer faydalı klinik etkilere sahip olamayacağına inandığı belirtilmiştir (10).

Glutatyon S-transferaz (GST) reaktif oksijen türleri (ROS), hormonların biyosentezi ve oksidatif strese karşı koruma dahil olmak üzere hem endojen hem de ksenobiyotik bileşiklere karşı en baskın koruyucu antioksidan enzim ailesinden biri olarak kabul edilmektedir $(11,12)$. Detoksifikasyon mekanizmasında sitokrom P450'nin aktivasyonunun yanı sıra, faz iki sistemi oksidanların konjugasyonu dahil olmak üzere çok işlevli bir rol oynar (13). Obezite ile mücadele amacıyla kilo kaybı üzerine, farklı yöntemlerin değerlendirildiği bir çok çalışma bulunmaktadır. Yapılan çalışmalar incelendiğinde; pek çoğunda kilo kaybına odaklanılmıştır. Ancak yaşanan kilo kaybının zaman gibi birçok faktörden dolayı bazı durumlarda yararından çok verdiği zararı göz ardı edilebilmektedir. Bu durum; bazen şok diyet veya aşırı egzersiz yüklenmesi ile, ani ölümlere kadar gidebilen istenmeyen sonuçlara yol açabilmektedir. Hızlı kilo kaybı ile aşırı oluşan ROS'ların temizlenmesi için GST'ye ihtiyaç vardır. Bundan dolayı GST düzeyleri, bu biriken ROS'lar için önemli bir göstergedir. Bu bilgiler doğrultusunda çalışmamızın amacı; 10 günlük kısa bir zaman diliminde egzersiz ile birlikte gözlenen kilo kaybının GST düzeylerine etkisinin araştırılmasıdır.

\section{GEREÇ VE YÖNTEMLER}

Çalışmanın niteliği deneysel hayvan çalışmasıdır. Yapılan bu çalışmada, hayvanlarla yapılan işlemler Aydın Adnan Menderes Üniversitesi (ADÜ) Tıp Fakültesi Deney Hayvanları Merkezi bünyesinde yapılmıştır. Çalışmada, ağırlıkları 380-465 gram arasında olan 10'arlı iki grup oluşturmak üzere 20 adet Wistar Albino erkek rat kullanıldı. Grupların 10'arlı olma nedeni çalışma esnasında ölüm riskine karşı, çalışmayı devam ettirmek amacıyladır. Erkek cinsi seçilme nedeni, kas kütlesinin dişi cinse kıyasla daha fazla olması sonucu egzersize daha dayanıklı olmasından ötürüdür. GST enzim aktivite analizi ADÜ Merkez Laboratuvarı bünyesinde çalışılmıştır.

\section{Hayvanlar Üzerine Yapılan İşlemler}

Öncelikle ratların koşu bandına ve egzersize adaptasyonunu sağlamak için çalışmadan önceki altı gün boyunca günde beş $\mathrm{dk}$ ve bir km/saat hızda hafif tempo koşu yaptırıldı. Daha sonra ratlarda kilo kaybı oluşturmak amacıyla subakut periyotta (beş günden fazla, 15 günden az) 10 gün boyunca orta düzeyde egzersiz yaptırıldı. Gronowska-Senger ve ark. (2009) 
uyguladıkları egzersiz modeli kullanıldı (14). Bu modele göre, ratlar 10 gün süreyle eğimsiz olarak $15 \mathrm{dk} /$ gün ve 20m/dk hızda treadmill koşu egzersizi yaptırılmaktadırlar.

Kilo kaybının, gruplar arasında fark oluşturması amacıyla niasin ve melatonin takviyesi verildi. Bu takviyelerin seçilmesi aşamasında; Canto ve arkadaşlarının ile Mostafavi ve arkadaşlarının çalışmalarından elde edilen bilgilerden yararlanıldı. Canto ve arkadaşlarının çalışmasında; Niasin takviyesinin NAD içeriğini ve enerji harcanmasını artırdığ belirtilmektedir (15). Mostafavi ve arkadaşlarının yaptığı meta analiz çalışmasında ise; melatoninin vücut ağırlığı üzerine olan değişikliklerde bir tampon olma rolünün olduğu hipotezi öne sürülmektedir (16).

Melatonin, Sigma-Aldrich firmasından bir gramlık toz prepatı halinde temin edilmiştir. Dozun belirlenmesi, verilme süresi belirlenirken; Reiter ve arkadaşlarının (2016) melatonin uygulamalarında geçmiş çalışmalara yönelik yaptığı çalışma göz önüne alınarak belirlendi. (17). Egzersizden 30-45 dk önce her bir hayvanın her gün tartımı yapılarak intraperitonal yoldan beş $\mathrm{mg} / \mathrm{kg} /$ gün doz şeklinde verildi.

Niasin, Sigma-Aldrich firmasından 100 gramlık toz prepatı halinde temin edilmiştir. Solüsyon dozunun belirlenmesi; Kwon ve arkadaşlarının (2018) çalışması baz alınarak belirlendi (18). Egzersizden 30-45 dk önce her bir hayvanın her gün tartımı yapılarak oral yoldan $360 \mathrm{mg} / \mathrm{kg} /$ gün niasin takviyesi verildi.

\section{Biyokimyasal Analiz}

Onuncu gün egzersiz bitimi ve ilaç uygulamasından bir gün sonra ketamin ve xylazin ile anestezi edilerek intrakardiyak yoluyla yaklaşık yedi ml kan örnekleri alındı. GST enzim aktivitesi analizi için; alınan kan örnekleri, 3000 rpm beş dakika santrifüj edildi. Serum örnekleri alındı.

GST enzim aktivite analizi için, Elabscience markanın kiti olan Glutathione-STransferase (Gsh-St) kolorimetrik analiz kiti ile kullanıldı. Bu analiz için, Biotek Epoch (Kanada) cihazı kullanıldı.

\section{İstatistiksel Analiz}

İstatistiksel analiz için SPSS for Windows 22.0 programı kullanıldı. Çalışmadan elde edilen veriler, ortalama \pm standart sapma $(\mathrm{X} \pm \mathrm{SD})$ olarak verildi ve 0.05 'in altındaki $\mathrm{P}$ değerleri, istatistiksel açıdan anlamlı olarak kabul edildi.

Her bir grupta bulunan ratların egzersizdeki ilk ve son gün vücut ağırlıklarının tartım sonuçları bağımlı örneklem t testi ile sınandı.

GST enzim aktivite sonuçları, George, D. \& Mallery, M. 2010 yılında çarpıklık ve basıklık değerler üzerinden yaptıkları normallik testi ile değerlendirildi. Verilerin normal dağılım gösterdiği için; Gruplar parametrik test olan bağımsız örneklem t testi ile karşılaştırıldı. Buna ek olarak GST enzim aktivite sonuçları ile kilo kaybı arasındaki ilişkiyi görmek amacıyla, parametrik korelasyon testi olan Pearson korelasyon analizi yapıldı.

\section{BULGULAR}

Yapılan bu çalışmada, egzersizin ilk ve son günü ratlar tartıldı. Tartım sonuçlarına göre; her grupta kilo kaybı gözlendi. Gözlemlenen bu kilo kaybının toplam vücut ağırlığı dikkate 
Adnan Menderes Üniversitesi Sağllk Bilimleri Fakültesi Dergisi 2021: 5(3); 575-582

Journal of Adnan Menderes University Health Sciences Faculty

alındığında; anlamlı olup olmadığg görmek amacıyla, bağımlı örneklem t testi ile sınandı (Tablo $1)$.

Tablo 1. Çalışmada oluşan kilo kaybının bağımlı örneklem t testi sonuçları

\begin{tabular}{ccc}
\hline & Grup 1 & Grup 2 \\
\hline İlk gün ort. (gr) & 440.7 & 418.3 \\
\hline Son gün ort. (gr) & 438.4 & 402.3 \\
\hline Fark (gr) & 2.3 & 16 \\
\hline P (sig.) & $>0.05$ & $<0.001$ \\
\hline
\end{tabular}

Bağımlı örneklem t testi sonuçlarına göre toplam vücut ağırlığı dikkate alındığında; çalışmanın olduğu 10 gün boyunca grup 1 de gözlemlenen kilo kaybı (2.3 gr) anlamlı bulunmamıştır ( $\mathrm{p}>0.05)$. Diğer taraftan, grup 2 de gözlemlenen kilo kaybı (16 gr) anlamlı bulunmuştur $(\mathrm{p}<0.001)$.

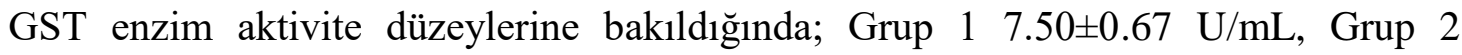
$5.52 \pm 0.72 \mathrm{U} / \mathrm{mL}$ olarak bulunmuştur (Şekil 1). Grupların GST enzim aktivite düzeylerinin karşılaştırılması için yapılan bağımsız örneklem t testi sonuçlarına göre; iki grup arasındaki fark anlamlı bulunmuştur $(\mathrm{t}=6.404, \mathrm{p}<0.001)$.

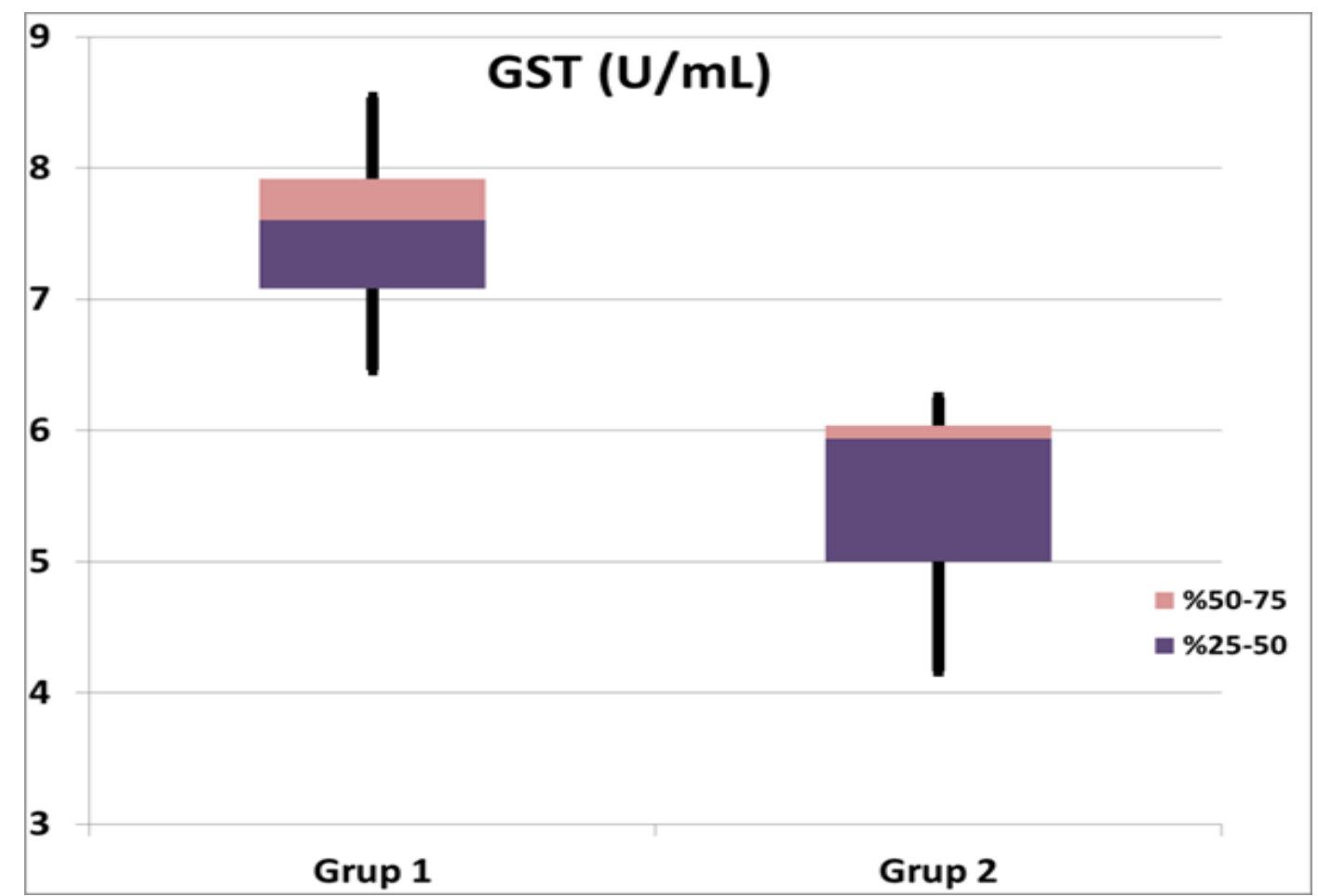

Şekil 1. Grupların GST enzim aktivite düzeylerinin box plot gösterimi

Çalışma boyunca oluşan kilo kaybı ile GST enzim aktivite düzeyleri arasındaki ilişkiyi görmek amacıyla Pearson Korelasyon analizi yapıldı.

Grup 1 değerlendirmeye katılması ile elde edilen korelasyon analiz sonuçlarına göre; çalışma boyunca oluşan kilo kaybı ile GST enzim aktivite düzeyleri arasında zıt yönlü bir korelasyon gözlenmiştir. Korelasyon kat sayısı $=-0.930$ olarak bulunmuştur $(p<0.001)$ (Tablo 2). 
Grup 2 değerlendirmeye katılması ile elde edilen korelasyon analiz sonuçlarına göre; çalışma boyunca oluşan kilo kaybı ile GST enzim aktivite düzeyleri arasında zıt yönlü bir korelasyon gözlenmiştir. Korelasyon kat sayısı=-0.939 olarak bulunmuştur $(p<0.001)$ (Tablo 2).

Tüm grupların değerlendirmeye katılması ile elde edilen korelasyon analiz sonuçlarına göre; çalışma boyunca oluşan kilo kaybı ile GST enzim aktivite düzeyleri arasında zıt yönlü bir korelasyon gözlenmiştir. Korelasyon kat sayısı=-0.977 olarak bulunmuştur $(p<0.001)$ (Tablo 2)).

Tablo 2. Çalışma boyunca oluşan kilo kaybı ile GST enzim aktivite düzeyleri arasındaki Pearson Korelasyon analizi sonuçları

\begin{tabular}{lll}
\hline Grup 1 $(\mathrm{n}=10)$ & $\mathrm{r}$ & -0.930 \\
& p. (2-yönlü) & $<0.001$ \\
\hline Grup 2 $(\mathrm{n}=10)$ & $\mathrm{r}$ & -0.939 \\
& p. (2-yönlü) & $<0.001$ \\
\hline Tüm gruplar $(\mathrm{n}=20)$ & $\mathrm{r}$. & -0.977 \\
& p. (2-yönlü) & $<0.001$ \\
\hline
\end{tabular}

r: Korelasyon katsayıs1

\section{TARTIŞMA}

Orta ve ağır düzeyde egzersizin kilo kaybı açısından bir strateji olması yanında oksidan aktiviteyi artırdığı ve organizmaya zararlı olduğu, sağlığı tehdit edebileceği bilinmektedir. Biz çalışmamızda Wistar Albino erkek ratlara subakut periyotta orta düzeyde egzersiz yaptırdık. Gruplar arasında kilo kaybı farkı oluşturmak amacıyla; bir gruba, Melatonin ve Niasini birlikte verdik. Bu şekilde egzersizde oluşan kilo kaybı ile GST enzim aktivitesi üzerindeki değişimini incelemeyi hedefledik.

Egzersiz, serbest oksijen radikallerinin üretimini artırarak oksidatif stres oluşturan bir stres kaynağı olmasına rağmen, antioksidan enzim aktivitesini etkileyerek oksidatif strese karşı direnç gelişmesini sağladığı da bilinmektedir (19). Egzersiz sırasında açığa çıkacak oksidan ve antioksidanların oranı egzersiz şiddetiyle değişim gösterir (20). Akut tüketici (ağır) ve şiddetli egzersizlerde hasar yapıcı oksidan sistem daha fazla aktive olurken düzenli ve kısa süreli maksimal olmayan egzersizler ise antioksidan sistemleri daha fazla aktive etmektedir (21-23). Yapılan bu çalışmada; 10 günlük egzersizle birlikte her iki grupta da kilo kaybı gözlendi. Her iki grubun GST enzim aktivitelerinin analizi yapıldı. Daha az kilo kaybı yaşayan grubun GST enzim aktivite düzeyleri, diğer gruptan daha yüksek gözlendi. Buna ek olarak gerek grup 1 gerek grup 2 de yaşanan kilo kaybının GST enzim aktivite düzeyleri ile yüksek düzeyde negatif korelasyon gösterdiği sonucuna ulaşıldı.

Obez ve normal kilolu çocuklar ile yapılan bir çalışmada; obez çocuklar ile normal kilolu çocuklar arasında MDA düzeyleri açısından anlamlı bir fark bulunmamıştır (24). Kilo kaybı üzerine obez çocuklar ile yapılan bir çalışmada ise; kontrol grubuna göre, obez çocukların vücut kitle indeksi (vki), bel-kalça oranı (bko) ve yağ kütlesi önemli ölçüde azalırken, lipit peroksidasyon göstergesi olan malondialdehitin (MDA) arttığı gözlenmiştir. MDA'nın bko, yağ kütlesi ve vki ile korele olduğu, oksidan durumun, altı aylık diyet kısıtlamasından sonra normale döndüğü tespit edilmiştir (25). Bunun yanı sıra, Sindhu ve arkadaşlarının diyabetik ratlarla yaptıkları bir çalışmada ise, ratların belli bir diyet programına tabii tutulmasından, sonra 
ratlarda belirgin kilo kaybı ile birlikte antioksidan enzim ailesinden olan Süper Oksit Dismutaz ve Katalaz aktivitelerinde azalma saptamışlardır (26). Bizim yaptığımız çalışmada da benzer şekilde kilo kaybı ile oksidan sistemin, antioksidan sisteme oranla daha fazla aktive olması ile birlikte, GST enzim aktivite düzeylerinde azalma saptanmıştır. Ayrıca, bu azalmanın kilo kaybı ile yüksek düzeyde korelasyon gösterdiği analiz edilmiştir.

Afshari ve arkadaşlarının yaptığı çalışmada; egzersiz şiddetinin arttığı durumlarda kilo kaybının artması ile birlikte, antioksidan verilmesinin oksidatif stresi tek başına mücadelede yetersiz kaldığ tampon olması amacıyla verilen melatonin, antioksidan bir takviye olmasına rağmen GST düzeyleri, oksidatif stres karşısında yetersiz kalmıştır. Bu durum oksidasyonu önlemek amacı ile GST’nin kullanıldığını göstermektedir. $\mathrm{Bu}$ konuda daha önce yapılan çalışmalarla uyumludur $(28,29)$.

\section{SONUÇ VE ÖNERILLER}

Sonuç olarak; 10 günlük subakut bir periyotta ratlarda egzersiz ile birlikte kilo kaybı oluşturuldu. Bu kilo kaybı, melatonin ve niasin takviyesi ile birlikte, toplam vücut ağırlığının yaklaşık \%4 düzeylerine kadar ulaştı. Bu kilo kaybı karşısında GST enzim aktivitesinde azalma gözlendi. Kilo kaybı ile GST enzim aktivitesi arasında zit yönde bir korelasyon olduğu sonucuna ulaşıldı.

\section{Araştırmanın Etik Yönü}

Deney hayvanları ile ilgili çalışma yapmak için gerekli olan etik kurul kararı, ADÜ HADYEK Merkezinde 23/03/2018 Tarihli 6453101/2018/039 Sayılı karar ile alınmıştır.

\section{Çıkar Çatışması}

Yazarlar arasında çıkar çatışması yoktur.

\section{Teşekkür ve Destekleyen Kuruluş}

Bu çalışma, Aydın Adnan Menderes Üniversitesi Bilimsel Araştırma Projeleri Birimi tarafından TPF 19011 proje numarası ile desteklenmiştir. Çalışma sürecinde yardımlarından dolayı ilgili birime şükranlarımızı sunarız.

\section{KAYNAKLAR}

1. Ward, Z. J., Long, M. W., Resch, S. C., Gortmaker, S. L., Cradock, A. L., Giles, C., et al. (2016). Redrawing The US Obesity Landscape: Bias-Corrected Estimates Of StateSpecific Adult Obesity Prevalence. PLoS ONE, 11(3), e0150735.

2. Jensen, M. D, Ryan, D. H, Apovian, C. M, Ard, J. D., Comuzzie A. G., Donato K. A., et al. (2014). 2013 AHA/ACC/ TOS Guideline for The Management of Overweight and Obesity in Adults: A Report of The American College of Cardiology/American Heart Association Task Force On Practice Guidelines and The Obesity Society. Circulation, 129(2), 102-138. 
3. Chin, S. H., Kahathuduwa, C. N., Binks M. (2016). Physical activity and obesity: what we know and what we need to know. Obesity Reviews, 17(12), 1226-1244.

4. Catenacci, V. A., Grunwald, G. K., Ingebrigtsen, J. P., Jakicic, J. M., McDermott, M. D., Phelan, S., et al. (2011). Physical Activity Patterns Using Accelerometry in the National Weight Control Registry. Obesity (Silver Spring), 19(6), 1163-1170.

5. Donnelly, J., Smith, B., Jacobsen, D., Kirk, E., DuBose K., Hyder M., et al. (2004). The role of exercise for weight loss and maintenance. Best Practice \& Research Clinical Gastroenterology, 18(6), 1009-1029.

6. MacLean, P. S., Higgins, J. A., Wyatt, H. R., Edward L. (2009). Regular exercise attenuates the metabolic drive to regain weight after long-term weight loss. American Journal of Physiology-Regulatory, Integrative and Comparative Physiology, 297(3), 793-802.

7. Doucet, E., King, N., Levine, J. A., Ross, R. (2011). Update on exercise and weight control. Journal of Obesity, Article ID 358205, 3 pages.

8. Child, R. B., Wilkinson, D. M., Fallowfield, J. L., Donnelly, A. E. (1998). Elevated serum antioxidant capacity and plasma malondialdehyde concentration in response to a simulated half-marathon run. Medicine \& Science Sports \&Exercise, 30, 1603-1607.

9. Ashtary-Larky, D., Ghanavati, M., Lamuchi, N., Payami, S. A., Alavi-Rad, S., Boustaninejad, M., et al. (2017). Rapid weight loss vs. slow weight loss: which is more effective on body composition and metabolic risk factors?. International Journal of Endocrinology and Metabolism, 15(3), e13249.

10. Da Luz, F. Q., Hay, P., Gibson, A. A., Touyz, S. W., Swinbourne, J. M., Roekenes, J. A., et al. (2015). Does severe dietary energy restriction increase binge eating in overweight or obese individuals? A systematic review. Obesity Reviews, 16(8) 652665.

11. Enayati, A. A., Ranson, H., Hemingway, J., (2005). Insect glutathione transferases and insecticide resistance. Insect Molecular Biology, 14, 3-8.

12. Hayes, J. D., Flanagan, J. U., Jowsey, I. R. (2005). Glutathione transferases. Annual Review of Pharmacology and Toxicology, 45, 51-88.

13. Jones, C. I., Zhu, H., Martin, S. F., Han, Z., Li, Y., Alevriadou, B. R. (2007). Regulation of antioxidants and phase 2 enzymes by shear-induced reactive oxygen species in endothelial cells. Annals of Biomedical Engineering, 35, 683-693.

14. Gronowska Senger, A., Gornicka, M., Kotodziejska, K. (2009). Tocopherol acetate vs. oxidative stress induced by physical exercise in rats. Polish Journal of Food and Nutrition Sciences, 59, 263-269.

15. Canto, C., Houtkooper, R. H., Pirinen, E., Youn, D. Y., Oosterveer, M. H., Cen, Y., et al. (2012). The $\mathrm{NAD}(+)$ precursor nicotinamide riboside enhances oxidative metabolism and protects against high-fat diet-induced obesity. Cell Metabolism, 15, 838-847.

16. Mostafavi, S. A., Akhondzadeh, S, Reza Mohammadi, M., Keshtkar, A. A., Hosseini, S., Reza Eshraghian, M., et al. (2017) Role of melatonin in body weight: A systematic review and meta-analysis. Current Pharmaceutical Design, 23(8), 3445-3452.

17. Reiter, R. J., Mayo, J. C., Tan, D. X., Sainz, R. M., Alatorre-Jimenez, M. Qin, L. (2016). Melatonin as an antioxidant: under promises but over delivers. Journal of Pineal Research, 61, 253-278.

18. Kwon, W. Y., Suh, G. J., Kim, K. S., Jung, Y. S., Kim, S. H., Lee, R., et al. (2018). Niacin and selenium attenuates brain 1njury after cardiac arrest by upregulatıng Dj-1Akt Signaling. Critical Care Medicine, 46 (1), 125. 
19. Aguilo, A., Tauler, P., Pilar, Guix, M., Villa, G., Cordova, A., Tur, J., et al. (2003). Effect of exercise intensity and training on antioxidants and cholesterol profile in cyclists. The Journal of Nutritional Biochemistry, 14, 319-325.

20. Radak, Z., Sasvari, M., Nyakas, C., Pucsok, J., Nakamoto, H., Goto, S. (2000). Exercise precondition in gagainst hydrogen peroxide induced oxidative damage in proteins of rat myocardium. Archives of Biochemistry and Biophysics, 376, 248-251.

21. Atalay, M., Oksala, N. K., Laaksonen, D. E., Savita, K., Chitose, N., Jani, L., et al. (2004). Exercise training modulates heat shock protein response in diabetic rats. Journal of Applied Physiology, 97, 605-611.

22. Banerjee, A. K., Mandal, A., Chanda, D., Chakraborti, S. (2003). Oxidant, antioxidant and physical exercise. Molecular and Cellular Biochemistry, 253, 307-312.

23. White, A., Estrada, M., Walker, K., Wisnia, P., Filgueira, G., Valdes, F., et al. (2001). Role of exercise and a scorbate on plasma antioxidant capacity in thorough bredracehorses. Comparative Biochemistry and Physiology, Part A Molecular and Integrative Physiology, 128, 99-104.

24. Çetin İ., Muhtaroğlu S., Keti D., Hatipoğlu N., Kurtoğlu S. (2013) Obez çocuklarda malondialdehit seviyesi ve paraoksonaz 1 aktivitesinin değerlendirilmesi. Sağllk Bilimleri Dergisi (Journal of Health Sciences) 22(1), 64-69.

25. Mohn, A., Catino, M., Capanna, R., Giannini, C., Marcovecchio, R., Chiarelli, F. (2005). Increased oxidative stress in prepubertal severely obese children: effect of a dietary restriction-weight loss program. The Journal of Clinical Endocrinology\&Metabolism, 90(5), 2653-2658.

26. Sindhu, R. K., Koo, J. R., Roberts, C. K., Vaziri, N. D. (2004). Dysregulation of hepatic superoxide dismutase, catalase and glutathione peroxidase in diabetes: response to insulin and antioxidant therapies. Clinical and Experimental Hypertension, 26(1), 4353.

27. Afshari, F., Ghosh, S., Khazaei, M., Kieffer, T. J., Brownsey, R. W., Laher, I. (2008). Exercise restores endothelial function independently of weight loss or hyperglycaemic status in db/dbmice. Diabetologia, 51, 1327-1337.

28. Flores, M. L., Nieto, N. L., Moreira, O. C., Iglesias, D. S. (2018). Effects of melatonin on sports performance: A systematic review. Journal of Exercise Physiology, 21(5), 121-138.

29. Stacchiotti, A., Favero, G., Rodella, L. F. (2020). Impact of melatonin on skeletal muscle and exercise. Cells, 9 (2), 288. 